Article

\title{
Home as Love: Transcending Positionality in Leila Aboulela's The Translator
}

\section{Ghadir K. Zannoun}

Modern and Classical Languages, Literatures and Cultures, University of Kentucky, Lexington, KY 40506, USA; ghadir.zannoun@uky.edu

Received: 1 January 2019; Accepted: 13 March 2019; Published: 9 April 2019

\begin{abstract}
Contrary to hegemonic Western representations of Muslim women as victims of Islam and Muslim men, Sudanese-Scottish Leila Aboulela's The Translator depicts a Muslim woman, Sammar, whose sense of home and belonging is predicated on her romantic love for her late cousin and husband, Tarig. Therefore, after his death, she feels alienated from her home in Sudan and leaves for Aberdeen, Scotland, where she is ostracized because she is Muslim. While this Muslim identity proves indispensable for her survival and gradual healing, ultimate normalcy and belonging are restored when she reclaims the world of love and acceptance she has lost with Tarig's death through a new relationship. The romantic love and the language she uses in this relationship allow Sammar to restore the sense of being and the belonging she had at home within the spaces she occupies in Aberdeen, ending her alienation and reclaiming her subjectivity. Using feminist theory and postcolonial theories of place and identity, as well as Lila Abu-Lughod's notion of emotional discourse as a pragmatic act, this study investigates the novel's depiction of place and identity as constructed entities embedded in emotion. This depiction, this study proposes, undermine various positionalities and binaries, such as self/other and east/west, allowing Aboulela to approach them more critically.
\end{abstract}

Keywords: postcolonial theory; Western representations of Islam and Muslim women; Orientalism; Othering; cultural difference; hybridity; home and belonging

In Language and the Politics of Emotion, Lila Abu-Lughod argues that "discourses on emotion or emotional discourses for that matter ... are implicated in the play of power and the operation of historically changing systems of social hierarchy" (Abu-Lughod and Lutz 1990, p. 28). This statement implies that discourses on emotions-as well as, one can also argue, emotions themselves-are nonessentialist and constructed. These implications about emotions and their discourses characterize the depiction of love, romantic and otherwise, in Leila Aboulela's The Translator. In this novel, the subjectivity and sense of place and belonging, at home and in diaspora, of the Muslim woman protagonist, Sammar, are predicated on romantic love that can be described, along with other forms of love and emotions, as a constructed part of her identity. In this close reading of the novel, I also argue that the language of emotion Sammar employs in her relationships functions as-to use Abu-Lughod's description of emotional discourse- a "pragmatic act" by means of which she maintains her restored sense of being and belonging. This depiction of emotion and its language in relation to identity and place reiterates the latter two also as fluid, nonessentialist entities while creating a site for Aboulela's double critique of both Arab society's patriarchy and hegemonic place-based notions, such as difference and culture, particularly the Western hegemonic construct of the Third World Difference, a central part of which is the essentialist representations of Islam as inherently oppressive to women. 


\section{Home as Love}

A sense of place that is grounded in emotions is in line with notions of place and identity as fluid, constructed entities, which is what the depiction of Sammar's identity, subjectivity, and sense of place and belonging - all that constitutes her difference-also confirm. Indeed, postcolonial theory of place foregrounds the nonessentialist nature and interdependence of both place and subjectivity:

Place therefore, the 'place' of the 'subject', throws light upon subjectivity itself, because whereas we might conceive subjectivity as a process, as Lacan has done, so the discourse of place is a process of continual dialect between subject and object ... This was not a place which was simply there but a place which is in a continual process of being written. (Ashcroft et al. 1995, p. 346)

Early on in the novel, Sammar's sense of place can be described as "a process of continual dialect between subject and object" that is mediated by social interaction and language, including the language of love. The novel begins with a dream that reveals Sammar's anxiety about not being able to meet Rae Isles, her Scottish employer, to whom she has recently become attracted, four years after moving to Aberdeen from Sudan following the death of her husband, Tarig: "She dreamt that it rained and she could not go out to meet him as planned. She could not walk through the hostile water, risk blurring the ink on the pages he had asked her to translate. And the anxiety that she was keeping him waiting pervaded the dream, gave it urgency that was astringent to grief" (Aboulela 1999, p. 3). Underlying these strong emotions are multiple anxieties that are revealed through first- and third-person narration. Right after this description of her dream, Sammar ponders her fear of the winter in Aberdeen, where she had been born and raised until the age of seven, to which she had returned with Tarig to study, and finally to which she has returned after his death:

She was afraid of the rain, afraid of the fog and the snow which came to this country, afraid of the wind even. At such times she would stay indoors and wait, watching from her window people doing what she couldn't do: children walking to school through the swirling leaves, the elderly smashing ice on the pavement with their walking sticks ... Last year when the city had been dark with fog, she hid indoors for four days, eating her way through the last packet of pasta in the cupboard, drinking tea without milk. On the fifth day, when the fog lifted she went out famished, rummaging the shops for food, dizzy with the effort. (Ibid.)

Although this passage presents alienation as mediating Sammar's relationship with her place, it does not posit it as intrinsic to her constitution or to the place's. It rather implies the relationship between Sammar's alienation and her inability to participate in the activities in which the others are involved, which seems to keep any attainment of a sense of belonging at bay. Significantly, practices such as walking or casual daily encounters between people or groups can give expression to what Tovi Fenster describes as "everyday belonging", which develops through men's and women's spatial knowledge of environments and their territorialization of them through daily interaction (Fenster 2005 , p. 243). By only staying inside and not participating in people's winter activities, Sammar fails to territorialize her place so that she can experience "daily belonging". While she could have experienced this type of belonging through different acts of territorialization, real belonging for Sammar, evidenced by her earlier life with Tarig, is grounded in and mediated by relationships based on acceptance and love. In Aberdeen, since Tariq's death, however, love and acceptance have been unattainable to her up to this point, as she is ostracized due to her Muslim identity.

By contrast, in the Sudan of Sammar's childhood and early adulthood, her physical interaction with place is mediated by these types of relationships, the most formative of which is her romantic relationship with Tarig, which gnaws at the Western stereotype of Arab and Muslim women as victims of an inherently oppressive Islam. As Mohja Kahf argues, although there are variations on the narrative representing the Muslim woman in Western culture, the core narrative is that she is a victim of an inherently oppressive Islam (Kahf 1999). Having started upon her arrival in Sudan for the first time 
at the age of seven, Sammar's love for Tarig becomes intrinsic to her sense of home, belonging, and even being. Therefore, it is Sammar's first arrival in Sudan as a child, not the first seven years of her childhood in Aberdeen, that becomes for her the first episode of her life story. When she tells Rae her life story, she begins with that event, only referring to her birth and earlier life in Aberdeen as a matter of fact: " ... when Rae asked her about Tarig. 'My aunt's son,' she replied, 'but it was not until I was seven that I met him. I was born here as you know and my parents and I did not go back home not until I was seven' ... . These were her words, the word 'until' as if she still could not reconcile herself to those first seven years of life without him" (Aboulela 1999, pp. 4-5). Her life/love story reveals, to use a term borrowed from Rosemary Sayigh, its primordiality, which "displaces more usual beginnings such as birth or first memories" (Sayigh 1998, p. 45). Earlier, she would even pretend she had always lived in Sudan so she could meet Tarig earlier: "In better times she used to reinvent the beginning of her life. Make believe that she was born at home in Sudan, Africa's largest land, in the Sisters' Maternity hospital, delivered by a nun dressed in white. She liked to imagine that Tarig was waiting for her outside the delivery room, holding his mother's hand, impatient for her" (ibid., p. 5).

This part of Sammar's story contrasts sharply with the Western stereotype of the "escapee" Muslim woman who strives to break away from her inherently cruel culture and oppressive Arab men (Kahf 2000, p. 149). On the contrary, her imaginary story envisions life starting in Sudan and within its Arabo-Islamic culture instead of outside of it. Therefore, after Tarig's death in a car accident while studying in Aberdeen, Sammar's thoughts of home constantly bring back her memories of him in Sudan. For example, when she ponders the possibility of returning to Sudan four years after his death, all recollections of him and their memories together come back: "To see home again. It was a chandelier on the ceiling of her life, circles of lights. To see again the streets where Tarig had ridden his bike ... To go to where everything happened, her aunt's house; laughter on their wedding, fire when she brought Tarig's body home" (Aboulela 1999, p. 33).

In light of the story of this formative love, Sammar's dream at the beginning of the novel can also be interpreted as a manifestation of her unconscious, which harbors her anxiety about getting into any new relationship, let alone one with a non-Muslim. Sammar's anxieties are grounded in both her love for her dead husband and her identity as a Muslim woman, for whom marriage to a non-Muslim man is considered taboo by Islamic culture. The rain in the dream can be understood to represent this taboo, an organic signature, a sign from nature that prevents Sammar from meeting Rae. At the same time, the dream reveals Sammar's anxiety about her relationship with Rae being short lived, as evidenced by her apprehension at keeping him waiting.

Similar to his love, Tarig's death shapes not only Sammar's subjectivity and sense of place but her body, leaving a physical mark on it, which can be interpreted as a symbol of her difference-a difference that is predicated on romantic love and the sudden loss of that love. The trauma of Tarig's death transfigures into physical pain with the shape of a diamond whose four corners point to the areas of pain Sammar starts to feel after his death. This pain-induced shape becomes a part of Sammar such that she compares it to other parts of her body, namely her hair and skin: "Her invisible mark shifted, breathed its existence. It was hidden from Rae, like her hair and the skin on her arms, it could only be imagined. Four years ago this mark had crystallized. Grief had formed, taken shape, a diamond shape, its four angles stapled on to her forehead, each shoulder, the top of her stomach" (ibid., p. 4). It is worth noting that the fact that Sammar wears a head covering, a marker of her Muslim identity, is mentioned in passing and only written into her thoughts, which implies its secondary role as an identity element, compared to her love for Tarig. Through this unobtrusive depiction, Aboulela gets away from what Mohja Kahf describes as "our era's obsession over the presence or absence of a veil" (Kahf 2008, p. 40).

Aboulela employs other tropes, such as personal names, to reiterate the impact of place-through its various socioeconomic life and the mediations of emotions and social interaction-on people. Had she been born in Sudan instead of Scotland, she tells Rae, she would have had a different name, "a more common one. A name suggested by her aunt, for she was a woman who had an opinion 
on all things" (Aboulela 1999, p. 5). Rae's last name, Isles, is reminiscent of the British Isles and the country's colonial history, whereas Sammar's name, as she tells Rae, is associated with the desert: "It means conversations with friends, late at night" (ibid.). Likewise, the poor condition of the political manifesto of the Egyptian Islamist radical group Al-Nidaa, which Sammar translates for Rae, bespeaks the place and the hard socioeconomic background of its authors: "The document was hand written, badly photocopied and full of spelling mistakes. It was stained with tea and what she guessed to be beans mashed with oil" (ibid., pp. 5-6).

With Tarig's death and the loss of his love in Aberdeen, the latter becomes meaningless space, propelling Sammar to get rid of all material traces of her previous life with Tarig there, turning her departure from Aberdeen and return to Sudan into an expedited evacuation. She takes her past life in Aberdeen apart, "tearing letters, dropping magazines in the bin, a furious dismantling of the life they had lived, the home they made" (ibid., p. 9). However, her return to the homeland proves just as alienating, now that she has to navigate it as it is, without the mediation of Tarig's love.

Aboulela's depiction of Sammar's post-Tarig Sudan exposes the country's patriarchal culture while highlighting the culture's complexity and mobility, which undermines claims of Arabo-Islamic culture's ahistoricity and lack of change. Like other cultures, elements of Sammar's culture can function as forces moving in opposite directions, prompting change and agency. These meanings play out in Sammar's new desire to remarry and the position of Mahasen, her aunt and mother-in-law, towards it. Having experienced Tarig's death as a total loss, Sammar comes to believe that she needs another marriage to help her refocus her life and get financial support. However, Mahasen refutes Sammar's reasons for marriage by reminding her that in "the past, widows needed protection, life is different now" and that her son is her focus (ibid., p. 13), adding, "An educated girl like you, you know English ... you can support yourself and your son, you don't need marriage. What do you need it for?" (ibid.). Mahasen's reference to modern women's economic independence inscribes Arab women as subjects of history, a fact that-as Amireh points out-is seldom acknowledged in Western representations of them (Amireh 1997, p. 187).

Although Mahasen's point about women's increasing economic independence exemplifies a cultural change to women's advantage, her domineering approach manifests the persistence of other forms of oppression, such as the universal expectations of motherhood and aspects of patriarchy, particularly the overarching power matriarchs can have. Representing one of these matriarchs, Mahasen coerces Sammar to comply with her desires and will as a sign reverence for her. In the end, Sammar plays the two societal expectations-having to act maternally and having to respect Mahasen's will—against each other. She deliberately misreads her aunt's cue-the statement that she should free herself from male dependency and take advantage of her education to make capital in the West-and returns to Aberdeen alone, without her son in tow. Sammar thus undermines society's pressure by heading it off with a difference. By returning to Scotland to make a living, Sammar complies with her aunt's will. However, by going back without her child, she undermines the maternal ties and emotions on which the aunt's demands are predicated. The novel thus destabilizes the Western category of the Muslim woman by revealing the ways in which Sammar's life is complicated not only by socioeconomic factors and culture but by love, death, and mourning. Ultimately, we are urged to recognize that "Muslim women's experiences ... are, like all women's experiences, ambiguous and highly variable, marked by subordination and opportunity, mobility and immobility, security and insecurity" (Nagel 2005, p. 4).

After she returns to Aberdeen, Sammar's life there turns out to be more painful than it was after Tarig's death, and she feels more disempowered than she was under Mahasen's control, which interferes with her sense of place. Not only does she still lack the love underlying her sense of place and being, but she is Othered for her Muslim identity, which turns her mourning for Tarig into depression and life in Aberdeen into an alienating exile. For example, her previous employer rarely speaks to her, and when she does, it is only in response to Sammar's difference. Failing to find any other common ground to initiate a conversation, the employer says, "My boyfriend is Nigerian", and pauses "as if that 
statement had a deeper meaning she wanted Sammar to grasp" (Aboulela 1999, p. 99). For Sammar, this statement is irrelevant and incomprehensible, making her feel "like a child who had stayed up too late at night and was discovering that in the adult world there were things she could not understand" (ibid., p. 100). The fact that Sammar is in a state of mourning and grief over her recently deceased husband does not signify for the employer as much as Sammar's hijab does: "Jennifer talked away fresh and brisk, reassuring her of how broad-minded and tolerant she was, not like so many people. 'For example,' Jennifer said, 'I have no problem at all with the way you dress'"' (ibid.). In such a context, where only her Islamic dress has significance, Sammar resorts to silence and enters into depressed state: "When Sammar finally spoke, she managed, 'Thank you,' and went home and slept. She slept deeply and continuously until the next day" (ibid.).

Others are similarly alienating for Sammar, as they react to her Muslim identity with various shades of surprise: "surprise-sneer, surprise-embarrassed, surprise-bemused, surprise-disapproving. She had to be silent. Use her teeth and lips to keep silent" (ibid., p. 45). The Translator is a manifestation that the silence Arab and Muslim women are accused of is not generated by or from within their culture alone, as the stereotype implies, but rather from outside of it as well. The novel depicts this silencing as the main source of oppression for Sammar, depriving her of the ability to think, to speak, to see, and to belong. Therefore, when Rae does not Other her for her difference, it is "[a]s if he had given her a promise, never to be taken aback" by anything she said and as if she is given a "permission to talk and think" and see again: "The same manners which made her talk to him, made the world vivid for the first time in years" (ibid., p. 6). This ends her alienation and depression and manifests place's embeddedness in language and social interaction.

\section{Place as a Palimpsest}

The constructed and subjective nature of place, and hence of difference and identity, is reiterated throughout the novel, as various places reveal their embeddedness in language as the latter; creates place where it does not exist. Following the dream with which the novel begins, Sammar meets Rae at the Winter Gardens, which feature various habitats from the world over in the heart of the foggy city. The Winter Gardens inscribe place as a palimpsest, where various places can exist on top of each other: "Tropical plants cramped in the damp warmth and orange fish in running water. Whistling birds flying indoors, the grey sky irrelevant above the glass ceiling" (ibid., 4). Moreover, at these gardens extensive language is used to define and describe the gardens to the public, implying the role of language in constructing place: "The door to the Winter Gardens (an extended greenhouse in Duthie Park) was covered with signs. So, no prams or pushchairs allowed, sorry no dogs allowed, opening hours 9.30 till dusk" (ibid.). Language, thus, not only helps define a place but contributes to its creation. Underlying this notion is a theory of place, which, as Ashcroft et al. note, "does not simply propose a binary separation between the 'place' named and described in language, and some 'real' place inaccessible to it but rather indicates that in some sense place is language, something in constant flux, a discourse in process" (Ashcroft et al. 1995, p. 345). Sammar also notes of Britain that "everything was labeled, everything had a name. She had got used to the explicitness" (Aboulela 1999, p. 4). Aboulela here alludes to the colonial history implied in naming, as suggested by Ashcroft et al.: " . . language always negotiated a kind of gap between the word and its signification. In this sense the dynamic of 'naming' become a primary colonizing process because it appropriates, defines, captures the place in language" (Ashcroft et al. 1995, p. 346).

Unlike how people in Aberdeen react to Sammar, Rae does not label her as an Other and instead sees her difference as grounds for locating their similarities. Therefore, when she and her Pakistani-Scottish friend Yasmine visit him in his house and she makes a reference to school uniforms in Sudan, instead of alienating him, Sammar's statement prompts Rae to talk about his own school uniform. When "she looked up [from a magazine article about schoolgirls in Somalia], Rae was watching her, a look in his eyes like kindness. Encouraged she said, 'I used to wear a uniform like that in secondary school'" (Aboulela 1999, p. 17). In response to Sammar's difference, Rae alludes to 
his own and hence his similarity to her: "They made us wear shorts even in the winter. It was awful, walking to school in the cold" (ibid.).

From that moment on, Sammar's relationship with Rae manifests again place's entanglement with emotions and social interaction. Once Sammar feels accepted, her sense of place changes from alienation to belonging. As a matter of fact, right after this conversation at Rae's house, Sammar literally feels at home, as Sudan transposes to Aberdeen for the first time. Outside Rae's house, "Sammar stepped into a hallucination in which the world swung around. Home had come here. Its dimly lit streets, its sky and the feel of home had come here and balanced just for her" (ibid., p. 21). Feeling at home, she finally restores the full use of her senses and faculties to physically experience home: "She saw the sky cloudless with too many stars, imagined the night warm, warmer than indoors. She smelled dust and heard the barking of stray dogs among the street's rubble and pot-holes. A bicycle bell tinkled, frogs croaked, the muezzin coughed into the microphone and began the azan for the Isha prayer" (ibid.). This is not merely feelings of homesickness engulfing her, Sammar reminds herself, for this "had happened before but not for so long, not so deeply" (ibid.); this time is different because the rules that kept her silent for long were being broken: "They broke when she said, in Rae's flat, her fingers on the magazine, 'I used to wear a uniform like that in school.' The rules broke and burst her head in little bright pieces" (Aboulela 1999, p. 45). Furthermore, once she has been accepted instead of ostracized, alienating Aberdeen becomes a potential signifying space that is experienced at the subconscious level, similar to home. That same night, after her visit to Rae's home, where she had felt she was back home, she has her first dream about Aberdeen-before that, she had only dreamed of Sudan. This was "her first dream of the present, the first time this grey landscape had found a place in her sleeping mind. Four years and her soul had dived into the past, nothing in the present could touch it" (ibid., p. 29).

Over the university break, Sammar and Rae exchange a few phone calls due to which Sammar continues to experience the simultaneity of home and diaspora, which reconfirms place as a palimpsest. Following one of Rae's phone calls, Sammar is engulfed again by the same feelings of being at home that have blurred the spatial and temporal boundaries between Sudan and Scotland, making her wonder, "Where was she now, which country? What year? She climbed the stairs into a hallucination in which the world had swung around. Home and the past had come here and balanced just for her" (ibid., p. 41). The feeling transforms the stairs of her apartment building into other "stairs in a warm yellow light and sounds of a party, people talking and someone laugh[ing]", and she is in the middle of all this "offering glasses of something that was dark and sweet" (ibid.). Rae's words, too, imply the simultaneity of places and times, as he tells Sammar that "he wanted to take her to places where she would forget and remember. Show her a bend in the Dee and she would see the Nile. Show her a house with a flat roof, a lighthouse that looked like a white minaret, castles where believers lived long ago, subservient to the climate" (ibid., p. 57). Therefore, when one of Rae's students asks her after the break if she had been anywhere for the holidays, she replies, "No", but, thinking of the time she had spent on the phone with Rae, she "felt that she had been away, far away to a place where she was content" (ibid., p. 72). The fact that places in the West can be reminiscent of home to the diaspora undermines claims about the essential difference between the East and the West and blurs their binary opposition.

A similar transposition of places and times occurs in Sudan as well. Contemplating her relationship with Rae before her visit to Sudan as part of a work trip to Egypt, Sammar anticipates that things she has come to know about him will become a part of her life in Sudan, occupying an equal space with older parts of it: "At home among people she had known all her life, she would remember things she had come to know about him" (ibid., p. 35). Foreshadowing his impact on her in Sudan, she realizes that "she would remember his timetable, lectures, tutorials, the names of the Ph.D students whose theses he supervised [ ... ] The names of books lined up on the wall of his office" (ibid., pp. 34-35). As Sammar goes home, her expectations come true, even more so than she had expected. Not only Rae's memories come to Sudan but Aberdeen itself. Home and exile trade places again, manifesting Fenster's argument that "in many cases belonging is also associated with past 
and present experiences and memories and future ties connected to a place, which grow with time" (Fenster 2005, p. 243). Undeniably, this definition of belonging renders incongruous limited notions of place and belonging, including nationalist belonging.

Sammar quickly restores her sense of place and being: "She ran up the stairs that she had often taken a step at a time, dragging her grief. Now the staircase had a different aura, a different light" (Aboulela 1999, p. 41). She now sees her apartment with new eyes: " .. ugly curtains, the faded bedspread [ ... ] She held these things in her hands, as if seeing them for the first time" (ibid., p. 67). For the second time she gets rid of stuff, just like she did in her expedited evacuation after Tarig's death: "Big black bags, putting things away, folding and putting things away in a bag [ ... ] But now there was no grief, no burning in her head and chest, she worked calmly, deciding what she wanted to keep and what she didn't" (ibid.). She finally transforms her "hospital room" into a new space, reflecting her new/old self.

Sammar's relationship with the public space also changes to one that offers her the sense of everyday belonging she lacked earlier. Unlike her years of seclusion and silence, she now goes shopping, takes walks in the city's streets, and participates in women's activities. By pointing out the different stores and places Sammar visits, the narrator implies that Sammar knows the place and has a new sense of daily belonging: "The shops were beginning to open their doors. Sammar passed a newsagent, a sports shop, fishmonger, bakery. The grocer shop which sold halal meat was closed; it opened late in the day. ..." (ibid., p. 66). Now she also does what others do: "Yesterday, she had been one of the people in search of bargains" (ibid., p. 67). She even feels like the others, underscoring the subjectivity of difference:

Things that jarred-an earring on a man's earlobe, a woman walking a dog big enough to swallow the infant she was at the same time pushing in a pram [ ... ] Now Sammar did not notice these things, did not gaze at them, alarmed, as she had done years before. Her eyes had grown numb over the years and she had found out, gradually, and felt reassured that she was not alone, that not everyone believed what the billboards said, not everyone understood why that woman kept such a large ferocious dog in her home. (Ibid., p. 70)

\section{Emotional Discourse as a Pragmatic Act}

The language Sammar uses in her relationship with Rae aims to maintain that relationship, which contributes to her recovery and reclamation of her sense of place and being. Alarmed by the others' alienating response to her difference, she eliminates from the life story that she tells Rae everything that can add to that difference. She wonders, "which part of the narrative to soften, to omit. How much of the truth could he take, without a look of surprise crossing his eyes? She had never said anything that surprised him before. And she wanted it always to be like that" (ibid., p. 6). Sammar's selective retelling of her life story is not a mere expression of her feelings towards him but a pragmatic act that has multiple social functions, the first of which—but not the only one-aims to maintain her newly restored belonging and acceptance. It serves the functions of emotional discourses as theorized by Lila Abu-Lughod, who argues,

We must understand emotional discourses as pragmatic acts and communicative performances ... in the public social world.... [E]motion talk must be interpreted as in and about social life rather than as veridically referential to some internal state.... [W] should view emotional discourse as a form of social action that creates effects in the world, effects that are read in a culturally informed way by the audience for emotional talk. (Abu-Lughod and Lutz 1990, pp. 11-12)

The pragmatic role of Sammar's edited story is similar to that of her emotional language towards Mahasen earlier in the story: "'I love your mother more than you,' she had teased [Tarig], "hugging her aunt, kissing her cheeks, putting her head on her shoulder" (Aboulela 1999, p. 10). Sammar's emotional language confirms the social role of emotions and their discourses. Indeed, "discourses 
on emotion or emotional discourses for that matter ... are implicated in the play of power and the operation of historically changing systems of social hierarchy" (Abu-Lughod and Lutz 1990, p. 28). Sammar's love for Mahasen can be understood as more than an extension of her love for Tarig and more as a recognition of her new social location as his wife. Sammar's marriage to Tarig situates her within a social group other than her immediate family, and her verbal expression of love for her mother in-law is an acknowledgment of this new affiliation and the hierarchy of this new order, at the top of which is her aunt/mother in-law. As Abu-Lughod reminds us, "to have certain feelings or at least to express particular sentiments becomes a political statement, if not a political act" (Abu-Lughod and Lutz 1990, p. 43).

Sammar's appropriation/reconstruction of her story through selective storytelling also signifies a reclamation of agency, as it reveals her engagement in an active introspection of what to include and what to eliminate. Her process results in a deepened consciousness and self-knowledge, characteristic of traveling women. As Aihwa Ong argues,

Changes engendered by emigration, marriage, divorce and children leaving home make women reflect on their lives ... Such examined lives bred in the liminal spaces between cultures and societies represent new imaginations about power and about the self, the kind of self-knowledge that can modify metropolitan theories of postcolonialism as multiple victimization. (Ong 1995, p. 367)

Indeed, Sammar becomes aware of identity as a complex of socially constructed—and hence inessential, different, and sometimes contradictory-elements, such as religion, culture, gender, sex, motherhood, and so forth. In one of these reflective moments, she describes her role as a mother as "a part", and hence a construct, of her identity: "She was unable to mother the child. The part of her that did the mothering had disappeared. Froth, ugly froth" (Aboulela 1999, p. 7). More importantly, whereas parts of Sammar's life in Aberdeen before meeting Rae depict her as a victim of Western racism, other parts, particularly the ones revealed through her self-assessment, reveal a complex constructed identity that has its own internal struggles, such as the struggle the Muslim part of her identity goes through.

Like other parts of her constructed identity, Sammar's Islam undergoes some tribulations and questioning, which undermines essentialist representations of it as inherently fixed and static, revealing it rather as a process arrived at through hard work and struggle. Upon Tarig's death, Sammar experiences difficulty holding on to her faith. While preparing to return to Sudan with his dead body, no sooner does she remind herself of God's will, repeating "Only Allah is eternal, only Allah is eternal", than she wonders, "Why is this lesson so hard to learn?" (Aboulela 1999, p. 9). When she returns to Aberdeen to face racism, holding on to this certainty whenever she thinks of the way Tarig died becomes even harder. At such moments, doubt, anger, and disbelief increasingly gnaw at her faith: "It never made sense. A gentle old man blinded by the sun, killing Tarig. The ifs were snakes hissing, if Tarig had gone out a minute earlier, a minute later, if ... The ifs were poisonous snakes, whispering. For years the ifs had tangled up her mind, tugged away at her faith, made her unable to walk up the stairs" (ibid., p. 58).

At the narrative level, the appropriated story Sammar tells Rae highlights the power and constructedness of representation, as well as the crucial role of mediating between experience and representation, as the latter conditions our reading of the represented subject. Therefore, her story can be seen as a parody of Western Orientalist feminists' representations of third world women, which are grounded in an Orientalist construction of what Chandra Mohanty calls the "Third World Difference":

And it is in the production of this "Third World Difference" that Western feminisms appropriate and "colonize" the fundamental complexities and conflicts which characterize the lives of women of different classes, religions, cultures, races and castes in these countries. It is in this process of homogenization and systemitization of the oppression of women in the third world that power is exercised in much of recent Western feminist discourse and this power needs to be defined and named. (Mohanty 1998, p. 335) 
Interestingly, what Sammar thinks of as a difference-her love for Tarig and travel to Scotland without her son-to be kept away from Rae is not bound by culture or religion. Her difference undermines the Third World Difference that is grounded in essentialist representations of both. Aboulela here undermines the usually Western attitude that considers Islam, to use Abu-Lughod's words, "that totalizing concept to which everything that happens in Middle Eastern societies tends to be reduced" (Abu-Lughod and Lutz 1990, p. 28). Sammar's difference is rather her emotions that undermine the universal images of the caring mother and loyal daughter, emotions that came into being as a result of the trauma of Tarig's death. She had said to her son, "I wish it was you instead. I hate you" (Aboulela 1999, p. 7). However, these emotions do not make it into the constructed story she tells Rae of why she left her child behind in Sudan. Instead, she tells the story as a manifestation of her aunt/mother in-law's strength and compassion: "My aunt is a strong woman", she tells Rae, "a leader really. She is looking after my son now. I haven't seen them for four years" (ibid.).

By contrast, through Sammar's introspections, Aboulela rewrites these untraditional emotions back into the novel-the emotions Sammar considers to be her insurmountable difference and therefore leaves out of her story. Whereas Sammar reveals a seamless story of romantic love that is more about Tarig and Sudan than about herself, Aboulela fills in the gaps with the missing elements, producing a more realistic, though less appealing, representation of her. Postcolonial feminists have stressed the necessity of representations of third world women as subjects in their own right. As Rey Chow argues, they need to be allowed to come forth "not as spectacles but in their contradictions" (Chow 1989, p. 104). In the case of Sammar, she "had given the child to Mahasen and it had not meant anything, nothing, as if he had not been once a piece of her, with her wherever she walked" (Aboulela 1999, p. 7). Sammar also keeps away from Rae how, as a daughter, she shunned her immediate family for the sake of the family of her love interest, Tarig, becoming an obedient child in that family for the purpose of ultimately having him for herself:

Tell him, she told herself, tell him of Mahasen and Tarig and Hanan. Mother, son, daughter. Tell him how you shrugged off your own family and attached yourself to them, the three of them. Made a gift of yourself, a child to be moulded.... An obedient niece, letting Mahasen decide how you should dress, how you should fix your hair. You were happy with that, content, waiting for the day you would take her only son away from her. (Ibid.)

\section{Further Destabilization of Stereotypes}

Aboulela employs Sammar's introspections and subsequent reclaimed subjectivity and agency as additional tools for destabilizing other Western misconceptions about Islam and Arab and Muslim women, such as some of the issues in what Amal Amireh calls the "usual laundry list of the eternal grievances of Arab woman" (Amireh 1997, p. 186), which includes, among other things, the veil, polygamy, frequent births, and women's lack of agency. Interestingly, Aboulela depicts these items, but from a totally different angle. Nowhere can this be seen more clearly than in the portrayal of Sammar's modest Islamic dress and head scarf: "She covered her hair with Italian silk, her arms with tropical colours. She wanted to look as elegant as Benazir Bhutto, as mesmerising as the Afghan princess she had once seen on TV wearing hijab, the daughter of an exiled leader of the mujahideen" (Aboulela 1999, p. 9). Unlike its Western image as a symbol of women's oppression and the backwardness of Islam (Ahmed 1992, p. 152), Sammar's veil is a manifestation of her subjectivity and agency, as she associates it with elegant fashion and hence constant change; power, signified by Bhutto, the Pakistani politician and prime minister; and the public space, including television, represented by Bhutto and the Afghan princess. Therefore, once Sammar recuperates from alienation and depression, she buys more scarves. This depiction of the veil also bespeaks the writer's larger strategy of "re-appropriating loaded Islamicisms from the lexicon of Western intolerance" (Nash 2002, p. 30), which also applies to her use of the word "mujahideen".

Likewise, if Sammar' story in Sudan reveals a young woman lacking in agency and subjectivity, it is attributed to her love for Tarig, which is to be read as a modern romance and an example of 
utter infatuation that obliterates the self in the other. Therefore, Sammar's memories of her own childhood are more about Tarig than about herself: "Their house, where you imagined you would one day live, the empty square in front of it ... Tarig's bike, Tarig's room, Tarig's singing with imaginary microphones, imaginary guitars ... " (Aboulela 1999, p. 7). In these recollections, Sammar even "fails" to differentiate between her acts and Tarig's: "Was it Tarig who always shaped designs in the dust with his feet? Or was it she? Shifted twigs, dented bottle tops, kicked around ... " (ibid., p. 27). Polygamy is also readdressed and situated in a different context that renders its hegemonic Western representation incoherent. Sammar's consideration of a polygamous suitor suggests the notion of polygamy as a possible alternative for some women that allows them to fill in an economic or emotional gap in the absence of other options. Aboulela even addresses the issue of frequent births in Muslim societies. In the course of the story, Sammar has two pregnancies, the first of which we know about through her recollection of Tarig, when she had miscarried, "on his hands and knees mopping the bathroom floor, her womb that had fallen apart" (ibid., p. 12).

Other Islamic traditions and practices are dislodged from their exoticized Western representations and stereotypical associations with fanaticism and fundamentalist ideology to convey to the reader their natural and familiar quality for the protagonists, as well as their historicity rather than their statis and fixity. For example, the ritual of fasting is depicted as a practice serving different social purposes, the way it is for most Muslims, rather than as an exotic and strict religious ritual. Through the emotions and enthusiasm typical of teens, the novel depicts the young Sammar's and her cousins' experience of fasting: "Sammar remembered [Tarig] fasting Ramadan when he was twelve and still going swimming, riding his bike in the burning heat of the afternoon, defiant and a little crazy, wanting to prove he was strong" (ibid., p. 32).

Instead of presenting Muslim culture and its practices as alienating for women, the novel's depiction of fasting suggests them as a site for nurturing their subculture. The defiant fasting practices of Tarig's childhood were not limited to boys. Girls participated in them to express their strength at some times and to emulate their mothers at others. Sammar recalls, "But they all had been like that, even the girls. Are you fasting? A cool yeah, or just a nod, deliberately casual, like it was not a big thing. Though later they would copy their mothers, my head aches, I can't bear it. I have lost weight, I can hardly eat at night" (ibid.). Implying its fluidity, the novel refers to how it is experienced differently in different places. With the days being shorter in Aberdeen, fasting Ramadan is totally different. It is "too easy, it doesn't count", Tarig used to tell Sammar jokingly. Likewise, the Muslim experience of the Qur'an is rendered through children's words and thoughts to convey their relevance and significance to them. As a child, Sammar had the words of the Qur'an to "recite in treacherous streets where rabid dogs barked too close. 'Say: I take refuge in the Lord of daybreak ... ', 'Say: I take refuge in the Lord of humans ... ' At night too, inside the terrifying dreams of childhood, she had said the verses to push away what was clinging and cruel" (ibid., p. 102).

For the novel's characters, Islam is like a second skin and a source of empowerment. By contrast, foregoing or adjusting these practices to fit the non-Islamic context proves painful. On days when her officemate, Diane, was not in, "Sammar prayed in the room, locking the door from inside.... It had seemed strange for her when she first came to live here, all that privacy that surrounded praying. She was used to seeing people pray on pavements and on grass" (ibid., p. 75). At the airport, it was time "to pray and the saddest thing was that there was nowhere to pray. ... Sammar prayed where she was, sitting down, not moving" (ibid., p. 132).

The novel also makes a distinction between Islam and culture, comparing divine law to humans' limited mindsets and laws. Therefore, for Sammar the Islamic law that stipulates that a widow must wait four months and ten days before seeking remarriage is much more reasonable than the harsher conditions humans impose on themselves, such as her own four-year mourning period: "Sammar thought, as she often thought, of the four months and ten days, such specifically laid out time, not too short and not too long. She thought of how Allah's Sharia was kinder and more balanced than the rules people set up for themselves" (ibid., p. 69). Likewise, contemplating her reasons for not going out 
alone with Rae, she critiques her society's sexist appropriation of the divine moral code. The Islamic sexual ethic demands virtue of both men and women. Society, on the other hand, is more lenient with its male members in matters of virtue and honor while insisting on women's reputation only. Sammar, by contrast, privileges the Islamic ethic of self-monitoring over both Western and Eastern notions of individual freedom. Providing an ethic that transcends place, geography, and culture, Islam here figures as a venue for a third space and a third vision: "But idols' powers are not infinite. They cover a place, a particular community and a time. Sammar watched Reputation lose its muscle, its vigour, shrink and frizzle out in this remote corner of the world. When idols fall, the path to the truth is uncluttered, clear. Who saw her, knew her, was with her all the time wherever she went?" (ibid., p. 57). She therefore apologizes to Rae for her inability to go out with him alone.

The Translator also exposes other Western claims about the subaltern in general and women in particular, such as the notion of progress as commensurate with women's financial advancement. The novel shows that the two are conditionally aligned. Right before her return to Sudan, Sammar gets a brief letter from Mahasen with an attached list of things she wants her to bring along, which makes Sammar think that "her aunt must imagine that she was making millions, an expatriate like those who found jobs in Saudi Arabia and the Gulf" (ibid., p. 87). Although she works in a Western country, Sammar is unable to meet financial expectations workers in some Arab countries are able to. The novel's questioning of taken-for-granted assumptions about women's status and advancement reiterates the call of the "narratives of postcolonial women [that] describe a political decentering that will be necessary in Western knowledge as it allows itself to be redefined by discourses from the geopolitical margins" (Ong 1995, p. 367).

The novel in general, and Aboulela's reinscription of Sammar's untold story in particular, also interrogates traditional women's travel narratives as well as reductionist assumptions about traditional and patriarchal societies. In Women's Travel Writing, Janis Stout contends that the moment of women's departure "entails a tension between the urge to break out, to shake the dust from one's feet, and an equally powerful homing urge, an urge to construct and maintain and to value relational ties" (Stout 1998, p. 36). Sammar's departure from Sudan, however, reverses and complicates this equation, as she is forced to leave for Aberdeen under Mahasen's pressure. Therefore, this departure does not stand for a desire on Sammar's part to break away from her past and present. On the contrary, Sammar ironically wants to opt for a very traditional, almost obsolete, role as a wife in a polygamous marriage. While undeniably playing an oppressive patriarchal role by interfering with Sammar's free will and desire to remarry, Mahasen ultimately helps her niece and daughter-in-law to achieve self-realization, which shows that the ways patriarchy operates and affects women are complicated. The relationship between Mahasen and Sammar also undermines the binary of self and community, especially in traditional society, as it implies that individualism is not always equivalent to self-realization and that it does not always conflict with communal identity and interest. Sammar's society, embodied in her aunt, prompts her separatism and individualism by directing her away from foolishly entering into a polygamous marriage for the wrong reasons.

Mahasen's and Sammar's relationship also undermines what JanMohamed describes as the "conflation of identity and location", which attempts to divide women's subjectivities along the East/West binary and other geographical boundaries (JanMohamed 1992, p. 97). The two women reiterate the incoherence of such divisions, as their subjectivities do not align with their locations. It is the young, educated Sammar, who spent part of her life in the West-not just as a child but when she returned with Tarig-who ponders an outmoded female role as a co-wife, whereas the older, less educated matriarch, who never lived in the West, holds more progressive views. It is Mahasen who reminds Sammar of the outmodedness of her thoughts about marriage. Neither is Mahasen restricted by rules of propriety typically linked to traditional culture: she does not invariably stand for the tradition and culture of her location. Referring to Ahmad Ali Yasseen, Sammar's polygamous suitor, she protests to Sammar, "He started to talk to me about this [marriage] and I silenced him. I shamed him, the old fool" (Aboulela 1999, p. 13). For her the man's religiosity and piety are irrelevant to 
his marriage proposal. Underlying Mahasen's attitude, at least seemingly, is a modern perspective of marriage as an enterprise based on intellectual and emotional compatibility rather than on any economic premise or religious conviction, both of which were Sammar's incentives for marrying him: "'He's religious,' Sammar had choked the words, 'he feels a duty towards widows'" (ibid.). In response to Sammar's interjection, Mahasen says, "He can take his religiousness and build a mosque but keep away from us" (ibid.). This again undermines Western assumptions about the role of religion in Arab and Muslim people's lives. According to Marina Lazreg, hegemonic Westerner representations depict religious dogma as the sole reality governing the Muslim and Arab women's lives (Lazreg 1990, p. 331).

Likewise, Yasmin's location in the West does not guarantee her a Eurocentric worldview. On the contrary, she-a secular Pakistani-Scottish Muslim, born and raised in Scotland-is more conservative than anyone else. She consistently reflects a monolithic non-Eurocentric worldview about the Other/West while still reducing everyone else to a single category by compartmentalizing people along the East/West divide, always "making general statements, starting with 'we,' where 'we' means the whole of the Third World and its people" (Aboulela 1999, p. 11). Yasmin's dual cultural background does not result in a hybrid identity, as she is not mixing the two cultures of her upbringing. Nonetheless, she stands for the perils of cultural hybridity by reinforcing the self/Other binary and using it as grounds for her claims of authenticity that legitimize her representations of self and Other. She often says, "We are not like them", or "We have close family ties, not like them" (ibid.). Her attitude goes under what Amireh describes as the misuses of hybridity in producing knowledge about the Other, in which hybridity "becomes a strategy of differentiation" (Amireh 1997, p.186). As a result, from her location in the West, she still produces essentialist and reductive knowledge about the West and the East.

\section{Transcending Positionality}

Sammar's reclamation of subjectivity and sense of belonging-through her newfound love and emotional language-gives her the opportunity to occupy two places, Sudan and Aberdeen. At a result, she continues the process of self-discovery, accompanying the occupation of in-between places, which she started earlier through storytelling. Such places, Iain Chambers maintains, provide the occasion for self-discovery, as the experiences and feelings we carry with us from a certain place are simultaneously "sustained across encounters and clashes with other histories, other places, other people", touched and shaped by these encounters (Chambers 1994, p. 4). Finally allowed to straddle a middle position between cultures, instead of being preventing from doing that as an Other, she has the occasion to examine her Arab culture, not only against Islam but against Rae's, without being constrained by Yasmin-like claims of cultural authenticity. When Rae spends the holidays with his ex-in-laws, she ponders:

Culture-shock for Sammar. An old man in Edinburgh was allowing his daughter's ex-husband under his roof. This must be civilized behavior, an "amicable divorce". Where she comes from, the divorced spouse was one who "turned out to be a son of dog" or "she turned out to be mad" and were treated as such. No one stayed friends, no one stayed on talking terms. (Aboulela 1999, p. 38)

Through such introspection, Sammar occasionally occupies what Casey Blanton calls a "nomad position" that entails "[u]nfixing oneself so that the place cannot equal truth[, which] allows one to embark upon a two-directional journey examining the realities of both sides of cultural differences so that they mutually may question each other" (Blanton 2002, p. 111). Such a process can also be described as cultural translation, which underlines the fact that cross-cultural and transnational experiences do not always result in cultural hybrids; very often a translation process occurs that allows for two worldviews to coexist without mixing.

Rae does a similar, but not identical, translation of Sammar's culture and religion, which she mistakes for a nomad position that can eventually allow him to examine and assess the realities of 
their two cultures' differences against each other. However, his position is only that of a neutral researcher who analyzes different points of view without assigning them a truth value. He has no problem representing opposite points of view from Christianity and Islam without believing in either. This particularly happens when he dwells on the Islamic meaning of speculating about God and translates/identifies its secular equivalent to Sammar. "In this society", he tells her, "in this secular society, the speculation is that God has put up this elaborate solar system and left it to run itself" (Aboulela 1999, p. 42). Blinded by her desire to find love again, Sammar fails to understand and acknowledge Rae's atheism, which is his difference, and instead interprets his academic behavior as a sign of potential conversion to Islam. She ponders how whenever they talk, he asks her questions and after she answers, "he [is] silent, as if he was thinking about what she had said" (ibid., p. 50).

Despite their positions' shortcomings, Rae's distant academic position and Sammar's failure to acknowledge his difference, their in-between-cultures locations still allow for some mutual enlightenment and understanding, through which knowledge flows in both directions. As the previous example implies, Sammar is able to provide answers to Rae's questions. Similarly, their discussions about the difference between the Qur'an and the Islamic sacred hadiths (the prophet's sayings), for example, turn out to be illuminating for both. Sammar is ignorant of that difference until Rae asks her about it, so when he unexpectedly asks about the difference between these sacred sayings and the Quran itself, "she [is] not prepared for that and falter[s] a little, saying that the book [is] upstairs, and she [will] have to get it" (ibid., p. 41). The occasion urges her to research and better understand her own religion, which culminates, interestingly, in a glimpse onto the Other. Therefore, it is after Sammar translates into English one of these sayings describing an important aspect of Islam's conceptualization of the human-God relationship that Rae provides its Western secular equivalent noted above (ibid., p. 42). These conversations "made her think" (ibid., p. 45), just as Rae would think about her answers.

Through such conversations, both Rae and Sammar inscribe themselves as producers of, to use Donna Haraway's expression, "situated knowledge" - knowledge that is partial and that reflects an awareness of the limitations of the location of its articulation (Haraway 1988). Such mutual enlightenment and "situated knowledge" need to redefine the traditional relationship between East and West, in which the "difference between self and Other is maintained as an opposition between knowledge and ignorance, change and stasis, feminist and victim" (Amireh 1997, p. 189). Both Rae and Sammar impart and receive knowledge, modifying the imperialist assumption that one, the West, always has the knowledge and the Other, the East, is the recipient.

However, this mutual enlightenment does not represent a real cross-cultural encounter, as described by Amireh, "with both learning about their differences, limitations and misconceptions, and moving towards mutual recognition, respect, sympathy, and a sense of the present relations that have obscured such mutual understanding" (Amireh 1997, p. 192). Sammar fails to understand or acknowledge Rae's difference as an atheist, which is the flip side of Othering on the basis of difference. By expecting him to convert to Islam on grounds of his previous contact with and knowledge of Muslim countries and culture, Sammar conflates identity and location. Although she is aware of his difference, including his atheism, she mainly remains fixated on his similarity to her: "They lived in worlds divided by simple facts—religion, country of origin, race-data that fills forms. But he doesn't drink anymore, she reminded herself ... and it had been another thing which made him less threatening ... not so different from her" (Aboulela 1999, p. 34). While she sometimes feels "separate from him, exiled while he was in his homeland, fasting while he was eating turkey" (ibid.), she quickly dismisses these differences and focuses on what makes him more familiar to her but different from the others: "From the beginning she had thought that he was not one of them, not modern like them, not impatient like them" (ibid.); his dark-enough skin, manners, and previous life in Muslim countries, in addition to his specialization in Middle Eastern history, make him look "out of place" in his own society (ibid., p. 6). She mistakenly interprets this difference from others as sameness to her, when she should have taken it for what it is: not sameness but similarity. T. Minh-ha Trinh notes that it is 
essential to dismantle the same/different binary in defining identity and to replace it with the notion of similarity (Trinh 1988, pp. 71-77).

Ultimately, Sammar's insistence on Rae's sameness erases his difference altogether. This erasure of difference underlies her expectation that he will immediately convert to Islam and her subsequent disillusionment when he does not. Her attempt at intervening in Rae's life only reverses the direction of intervention between colonialist and neocolonialist systems and the colonized; in both cases, the difference between the colonial power and the colonized or between the self and the Other is equivalent to the difference between knowledge and ignorance. Hence, knowledge-or rather, more knowledge-about Islam is what Sammar thinks Rae needs if he is to convert:

She thought of what she would tell him, all the things she would translate for him. He knew a lot. Like others here, this world held his attention and the scope of his mind. But he did not know about the stream of Kawthar, the Day of Promises or what stops the heart from rusting. And the balance he admired. He would not understand it until he lived it. (Aboulela 1999, p. 118)

Sammar's assumption is quickly revealed to be far from accurate, for when she approaches the subject of conversion, Rae seems to know exactly what she wants to talk to him about: "Is the shahadah [the verbal declaration of one's belief in or conversion to Islam] what you want to talk to me about?" he asks her immediately (ibid., p. 123). Her explanation of the shahadah for him presumes his total ignorance and her exclusive knowledge: "It's two things together, both beginning with the words, 'I bear witness", (ibid.). Attempting to be clear and convincing, she ends up using simplified language that implies that Rae is totally ignorant of Islam: "There were messengers before, Moses and Jesus and others. Every messenger comes with proof about himself, a miracle suitable to his time.... The Qur'an was the miracle that Muhammad, peace be upon him, was sent with" (ibid., p. 124). Although Rae himself fills the gaps left out by her lack of complete knowledge, she continues to act as teacher and a moralist. When she fails to explain why women and slaves were the first Muslim converts, he interjects, "Maybe in changing they did not have much to lose.... It was the rulers of Makkah who were reluctant to give up their traditions and established ways for something new" (ibid.). Undeterred by her own lack of knowledge, she asks him, "Now tell me if you believe or not" (ibid.).

Even when he assures her that he does know the meaning of Islam to its faithful, she is still unable to frame conversion and faith outside the realm of factual knowledge. Finding him unresponsive, she asks, "Do you know what it means for us?" Despite his affirmative answer-“I know, I've always known" (ibid., p. 125)—she still demands his immediate conversion so that they can get married: "I imagined that we could get married today" (ibid.). Even more, she declines his request to have more time, accusing him of deceit and incompetence: "There really must be something wrong with you to have been divorced twice, not once but twice" (ibid., p. 129). Sammar's positionality transforms the love relationship into a battlefield where neither one comes out victorious, which is a complete departure from her earlier harmonious conversations with him. "Get out of here.... Get away from $\mathrm{me}^{\prime \prime}$, he finally demands of her (ibid.). The Translator underlines the pitfalls of reductionist identity politics based solely on either sameness or difference, instead of the recognition of both at the same time.

When it comes to other people from the Middle East, Rae too reveals a similar positionality. Implied in this regression is the role of hierarchical power relations between East and West in shaping his knowledge and language. Occupying a powerful location as a Western academic expert on the Middle East and the third world, he too oscillates between different positions towards the Other. However, as discussed previously, he seems in his relationship with Sammar to acknowledge her difference, seeing it as grounds for similarity. He also frequently implies the significance of her background: "But if you go home, you would find it hard to come back and I would not have a translator any more" (Aboulela 1999, p. 29). He thus reveals not only his awareness but understanding of her commitment to her people and country—that "she was heavy with other loyalties, full to the brim with distant places, voices in a language that was not his own" (ibid.). However, he cannot totally escape the implications of his location as a Western academic. Rae's positionality is reinscribed, in part, by his society's power structure and its knowledge system, a fact that can be delineated by the 
significance of the epithet attached to him in the media. Though his primary specialty is Middle East history and third world politics, he is referred to as an Islamic expert, reflecting a typical imperialist mindset that jumbles the rest of the world into a single category called, in this case, Islam. In Western hegemonic discourse Islam is synonymous with the ultimate Other and, therefore, is understood to stand for all the incompatible categories of third world and Middle East, as well as their histories and politics.

Although he is resistant to this conflation, insisting that "there could be no such monolithic" (ibid., p. 5), he still reinscribes the same hierarchical binaries of self/Other and subject/object that characterize East/West relations and interventions. Instead of treating his expertise as situated-and hence partial-knowledge, he plays the role of the Western expert who has the right to pass undifferentiated judgments about a conflated Other. Referring to the Islamist Al-Nidaa group, Rae figures as the sole producer of knowledge about the group, implying not only his subject position but the group's object status. Whereas Sammar sees the humans and their feelings behind the manifesto, he sees only ideology. "It is sad", she tells Rae. "There is something pathetic about the spelling mistakes, the stains on the paper, in spite of the bravado.... You get a sense of people overwhelmed ... by thinking that nothing should be what it is now" (ibid., p. 26). Echoing an imperialist mindset that conflates the rest of the world into a single group, Rae responds, "They are all like that" (ibid.). He also renders the human-centered language with which Sammar describes them irrelevant by switching the discussion to their ideology and logic instead of humanity and feelings: "They are shooting themselves in the foot. There is no resource in the Sharia for what they're doing, however much they try and justify themselves" (ibid.). Underlying Rae's refusal to address the group's psychological vulnerability is the Orientalists' depiction of the Other as "less sensitive" and ultimately "less human" than they (Amireh 1997, p. 196).

Indeed, Rae's language reveals a centralized discourse that perpetually reinscribes his subject position. In fact, he confesses that his interest in Islamist groups is an objectification of them: "But really it would have been good for the department ... to prove ourselves useful to industry or the government to keep the funding coming in" (Aboulela 1999, p. 27). Despite his sympathies, he still operates from a centralized knowledge system that resists definition by the Other's discourse, hence his anger when people expect him to convert. Such a conversion would place him in an equal object position, similar to the one occupied by the Muslims he analyzes, which undermines the binary opposition underlying his relationship to them. By expecting his immediate conversion, Sammar overlooks these power relations underlying Rae's subject position.

Ironically, Yasmin, on the other hand, does exactly the opposite. Whereas Sammar, blinded by her longing for love, insists on her similarity to Rae, refusing to acknowledge the implications of his difference as a secular Western academic, Yasmin cannot see or even imagine any other identity beyond that delineated by his academic position. She therefore dismisses all that Sammar considers as possible signs of conversion. In response to Sammar's reference to his different manners and niceness, Yasmin says, "Atheists can be as nice as anyone else. Being good or kind has nothing to do with it" (ibid., p. 93). When Sammar still refers to the fact that Rae believes in the sacredness of the Qur'an like Muslims do, Yasmin responds, "That's the way they do research nowadays. It's a modern thing. Something to do with being Eurocentric. They take what each culture says about itself. So they could study all sorts of sacred texts and be detached" (ibid., pp. 93-94). Underlying her attitude is not only a concern with the Islamic law that prevents the marriage of Muslim women to non-Muslims, but an identity politics grounded in difference as Otherness. "Go home", she tells Sammar, "and maybe you'll meet someone normal, someone Sudanese like yourself. Mixed couples just don't look right, they irritate everyone" (ibid., p. 93).

Rae's story of his travels to Africa exposes more salient examples of his subscription to a reductionist notion of difference that, this time, exoticizes that difference instead of Othering it. The novel renders this approach reductive as well and highlights its implications. For example, the fact that he has Muslim cousins in Egypt is for him an exciting and romantic idea. Moreover, by seeking 
the exotic Other in their relationship, Rae and Amelia-his first wife, who was half Spanish and half English, whom he had met in Morocco-had been reduced to their difference and hence to mere exotic images that were ultimately deflated. In Morocco, "according to the ladies, [Rae] looked exactly like an Arab" (ibid., p. 60). Likewise, for Rae, "Morocco was [Amelia's] home, it was in her Spanish blood, her English spoken with a certain lilt-her attraction for Rae" (ibid., pp. 60-61). Once married, Amelia had not taken to the reality of Rae's unsettled life in Morocco. Rae, too, had contemplated the repercussions of his premature marriage: "Money worried Rae. His brain thought money, money, his heart hurt. ... He got into debt and began to have nightmares about Moroccan prisons" (ibid., p. 62). The ultimate manifestation of the relationship's flawed basis was their disfigured, stillborn baby.

\section{Conclusions}

Through the depiction of the pragmatics of emotions and emotional discourse, The Translator manifests the reductionism and incoherence of identity politics based on fixed notions of difference and place/location, reinscribing these notions as relative and fluid parts of identity. While underscoring this fluidity, The Translator exposes the implication of identity politics in power structures and relations. The novel also complicates assumptions about the transformative power of travel, hybridity, and liminality by highlighting its protagonists' oscillation between these different locations. Aboulela's characters move back and forth between a territorialized or positional identity based on the self/Other binary and a more flexible and deterritorialized one that, to use Ong's words, "presupposes a dynamic process of disowning places that come with overly determined claims and re-owning them according to different (radical democratic) interests" (Ong 1995, p. 68). The novel, thus, implies that perpetuating true cross-cultural relations is difficult and complex and that mutual vigilance is needed if reductionist notions of difference and identity, as well as the fixation on positionality, is to be kept at bay.

The protagonists' vigilance and true understanding of each other is finally achieved when they suspend their positionalities. Interestingly, Sammar is able to do that at the end of the novel through her faith, which, when she fully reclaims it, better informs her understanding of Rae's difference by way of a better comprehension of conversion. After their argument, Sammar leaves for Sudan, where she has the space and time to think straight and contemplate the meaning of conversion, realizing her mistakes in Aberdeen. Unlike her earlier position, she finally recognizes that people who draw others to Islam do it "for no personal gain ... for Allah's sake ... with no ego involved. And she, when she spoke to Rae, wanting this and that, full of it; wanting to drive with him to Stirling, to cook for him, to be settled, to be someone's wife" (Aboulela 1999, p. 175). She now attempts to put her own interests aside and pray for his own sake, consigning the matter thus to the divine: "If she could rise above that, if she would clean her intentions ... " (ibid.). By putting her personal interests and ego aside, she transcends her positionality, which only saw Rae's similarity to her. She now recognizes his difference from her alongside other aspects of his identity that make him easier to relate to, such as his kindness. Now her wishes for him to convert emanate from her appreciation of his goodness, a manifestation of true love rather than a means for personal gain: "He had been kind to her and she had given him nothing in return. She would do it now from far away without him even knowing. It would be her secret. If it took ten months or ten years or twenty or more" (ibid.). Interestingly, this meaning of conversion recognizes the "other" as both different and similar and acknowledges his/her needs as a human being, which is the identity politics for which the novel calls.

Likewise, when Rae converts and visits Sudan as a Muslim, he confirms to Sammar what both of them were oblivious to earlier: "I found out at the end that it didn't have anything to do with how much I've read or how many facts I've learned about Islam. Knowledge is necessary, that's true. But faith, it comes direct from Allah" (ibid., p. 198). Rae's final understanding of conversion perpetuates their cross-cultural dialogue, as it prompts him to operate from outside power structures. His conversion becomes possible only when he no longer approaches Islam as an object of study but as a difference to be really understood and acknowledged: "At the end it was one step that I took, of wanting it for myself separate from the work, and then it all rushed to me" (ibid., p. 199). The novel's happy ending, 
with Rae's and Sammar's reunion, is the result of this suspension of positionality and power relations within which the couple's relationship was operating. With this reunion, they both arrive home, where home, as bell hooks notes, is "no longer just one place. It is locations. Home is that place which enables and promotes varied and ever changing perspectives, a place where one discovers new ways of seeing reality, frontiers of difference" (qtd. in Massey 1994, pp. 171-72). The novel's ending reiterates the notion that place/location/home, along with all that location comprises, such as culture, religion, relationships, and even emotions-all of which usually become grounds for difference-are highly variable constructs of identity and subjectivity.

Funding: This research received no external funding.

Acknowledgments: I am grateful for the anonymous reviewers for their insightful suggestions.

Conflicts of Interest: The author declares no conflict of interest.

\section{References}

Aboulela, Leila. 1999. The Translator. New York: Black Cat.

Abu-Lughod, Lila, and Catherine A. Lutz, eds. 1990. Language and the Politics of Emotion. New York: Columbia University Press.

Ahmed, Leila. 1992. Women and Gender in Islam: Historical Roots of a Modern Debate. New Haven: Yale University Press. Amireh, Amal. 1997. Writing the Difference: Feminists' Invention of the 'Arab Women'. In Interventions: Feminist Dialogues on Third World Women's Literature and Film. Edited by Bishnupriya Ghosh and Brinda Bose. New York: Garland Publishing, pp. 185-211.

Ashcroft, Bill, Gareth Griffiths, and Helen Tiffin, eds. 1995. The Post Colonial Studies Reader. London: Routledge. Blanton, Casey. 2002. Travel Writing: The Self and the World. New York: Psychology Press.

Chambers, Iain. 1994. Migrancy, Culture, Identity. New York: Routledge.

Chow, Rey. 1989. "It's You and Not Me": Domination and "Othering" in Theorizing the "Third World". In Coming to Terms. Edited by Elizabeth Weed. New York: Routledge.

Fenster, Tovi. 2005. Gender and the City: The Different Formations of Belonging. In A Companion to Feminist Geography. Edited by Lise Nelson and Joni Seager. Malden: Blackwell Publishing, pp. 242-56.

Haraway, Donna. 1988. Situated Knowledge: The Science Question in Feminism and the Privilege of Partial Perspective. Feminist Studies 14: 575-99. [CrossRef]

Massey, Doreen. 1994. Space, Place and Gender. Cambridge: Polity.

JanMohamed, Abdul. 1992. Worldliness-without-World, Homelessness-as-Home: Towards a Definition of the Specular Border Intellectual. In Edward Said: A Critical Reader. Edited by Michael Sprinker. Oxford: Blackwell, pp. 96-120.

Kahf, Mohja. 1999. Western Representations of the Muslim Woman: From Termagant to Odalisque. Austin: University of Texas Press.

Kahf, Mohja. 2000. Packaging "Huda": Shaarawi's Memoirs in the United States Reception Environment. In Going Global: The Transnational Reception of Third World Women Writers. Edited by Amal Amireh and Lisa Suhair Majaj. New York: Garland, pp. 148-72.

Kahf, Mohja. 2008. From Her Royal Body the Robe Was Removed: The Blessings of the Veil and the Trauma of Forced Unveilings in the Middle East. In The Veil: Women Writers on its History, Lore and Politics. Edited by Jennifer Heath. Berkeley: University of California Press, pp. 27-43.

Lazreg, Marina. 1990. Feminism and Difference: The Perils of Writing as a Woman on Women in Algeria. In Conflicts in Feminism. Edited by Marianne Hirsch and Evelyn Fox Keller. New York: Routledge, pp. 326-48.

Mohanty, Chandra. 1998. Under Western Eyes: Feminist Scholarship and Colonial Discourses. Feminist Review 30: 61-88. [CrossRef]

Nagel, Caroline. 2005. Introduction. In Geographies of Muslim Women. Gender, Religion and Space. Edited by Ghazi-Walid Falah and Caroline Rose Nagel. New York: The Guilford Press.

Nash, Geoffrey. 2002. Re-Sitting Religion and Creating a Feminised Space in the Fiction of Ahdaf Souif and Leila Aboulela. Wasafiri 17: 28-31. [CrossRef] 
Ong, Aihwa. 1995. Women Out of China: Traveling Tales and Traveling Theories in Postcolonial Feminism. In Women Writing Culture. Ruth Behar and Deborah A. Gordon. Edited by Ruth Behar. Berkeley: University of California Press, pp. 350-72.

Sayigh, Rosemary. 1998. Palestinian Camp Women as Tellers of History. Journal of Palestine Studies 27: 42-58. [CrossRef]

Stout, Janis. 1998. Through the Window: Out the Door: Women's Narrative of Departure, From Austin and Cather to Tyler, Morrison and Didion. Tuscaloosa: University of Alabama Press.

Trinh, T. Minh-ha. 1988. Not You/like You: Post-Colonial Women and the Interlocking Questions of Identity and Difference. Inscriptions 3: 71-77.

2019 by the author. Licensee MDPI, Basel, Switzerland. This article is an open access article distributed under the terms and conditions of the Creative Commons Attribution (CC BY) license (http://creativecommons.org/licenses/by/4.0/). 